\section{Cryobiology}

Volume 53, Issue 1 , August 2006, Pages 28-36

http://dx.doi.org/10.1016/j.cryobiol.2006.03.008

(c) 2006 Elsevier Inc. All rights reserved
Archimer, archive institutionnelle de l'Ifremer http://www.ifremer.fr/docelec/

\title{
Cryopreservation of Crassostrea gigas vesicular cells: Viability and metabolic activity
}

\author{
A.C. Hanquet-Dufour ${ }^{a}$, K. Kellner ${ }^{a}{ }^{,}{ }^{*}$, C. Heude ${ }^{a}$, A. Naimi ${ }^{a}$, M. Mathieu ${ }^{a}$ and J.M. Poncet ${ }^{b}$
}

\begin{abstract}
aUMR PE2M, Laboratoire de Biologie et Biotechnologies Marines, UMR 100 Ifremer (Physiologie et Ecophysiologie des Mollusques Marins), Université de Caen, Esplanade de la Paix, F 14032 Caen Cedex, France

${ }^{\mathrm{b}}$ Plateau de Cryobiologie, ISBIO, Université de Caen, Esplanade de la Paix, F 14032 Caen Cedex, France
\end{abstract}

*: Corresponding author : Fax: +33 2315653 46; kristell.kellner@unicaen.fr

\begin{abstract}
Cryopreservation is widely used for long-term conservation of various tissues, embryos or gametes. However, few studies have described cryopreservation of invertebrate primary cell cultures and more particularly of marine invertebrate somatic cells. This technique would however be of great interest to facilitate the study of various metabolic processes which vary seasonally. The aim of the present study was to develop a protocol for cryopreservation of Crassostrea gigas vesicular cells. Different parameters were adjusted to improve recovery of cells after freezing. The most efficient cryoprotectant agent was a mix of $\mathrm{Me}_{2} \mathrm{SO}$, glycerol, and ethylene glycol (4\% each). The optimal cooling rate was $-1{ }^{\circ} \mathrm{C} \mathrm{min}^{-1}$ down to $-70{ }^{\circ} \mathrm{C}$ before transfer into liquid nitrogen. In these conditions the percentage of viable cells reached $70 \%$ of the control. The glucose metabolism of thawed cells was evaluated using radioactive glucose as a tracer. Immediately after thawing, glucose uptake involving membrane transporters was greatly reduced ( $24 \%$ of control) whereas glucose incorporation into glycogen was less affected (68\% of control).
\end{abstract}

Keywords: Crassostrea gigas; Oyster; Mollusc; Cryopreservation; Vesicular cells; Glycogen metabolism 


\section{Introduction}

Growth and reproductive activity of the oyster Crassostrea gigas are mainly supported by glycogen reserves stored in vesicular cells, constituting the storage tissue. This storage tissue is located in the labial palps, the mantle, the gonadal area, at the base of the gills and around the digestive gland [3]. Vesicular cells have been the focus of many studies because of their involvement in energetic support of gametogenesis [2, 16, 20, 29, 43]. Suspensions of isolated vesicular cells were used for investigation of metabolic activity by in vitro bioassays $\left({ }^{14} \mathrm{C}\right.$ Glucose uptake and its incorporation into glycogen) [4]. This in vitro approach demonstrated a clear seasonality in glucose metabolism in oysters, inversely correlated with the reproductive cycle, with glycogen storage in autumn and mobilisation of reserves in spring to support gonadal development. In vivo experiments in which labelled glucose was injected into whole animals confirmed the seasonal variations of glycogen metabolism [21]. The seasonal cycle of accumulation and mobilisation of storage products is not strictly correlated with availability of food. It is probably heavily influenced by endocrine regulation in response to the high energy demand associated with reproduction and growth in summer. Identification of the factors involved in this regulation as well as characterisation of the regulatory mechanisms are among our main research objectives. However, this requires testing and comparison of the biological effects of extracts or of potentially active substances from living vesicular cells with metabolic activity oriented both towards the build up of reserves (autumn / winter) and towards mobilisation of reserves (spring / summer). Until present, these effects were by necessity tested on freshly isolated cells at 6 month intervals, but it is obviously problematic to compare the results of totally independent experiments, particularly in animals which exhibit high levels of variation both between individuals and inter-annually. For this reason we envisaged cryopreservation of reference batches of metabolically characterised vesicular cells in liquid nitrogen as a complementary approach which would allow simultaneous testing of regulatory factors in strictly identical experimental conditions. In this manner, analytical biases associated with, for example, variable receptivity of target cells, can be reduced. The feasibility of cryopreservation of these vesicular cells was the object of the present study.

Cryopreservation was developed mainly for long term storage of vertebrate cells, tissues and embryos. Few studies have reported successful of cryopreservation of molluscan cells. Of these, most involve germinal cells or embryos (Table 1); spermatozoa were successfully cryopreserved in Crassostrea tulipa, Crassostrea virginica, Crassostrea gigas and cryopreservation has been tested on oocytes of Crassostrea gigas. Embryos and larvae from various species including Crassostrea virginica and Crassostrea gigas have also been the subject of attempts at cryopreservation, but several authors have underlined the difficulty of maintaining structure and activity of embryos after thawing [41, 6, 7, 33, 27]. Concerning differentiated somatic cells, Crassostrea virginica and Pecten maximus cardiac cells were successfully cryopreserved as were dissociated mantle cells and hemocytes from the gastropod Haliotis tuberculata. For these molluscan cell types, several cryoprotectant agents (CPAs) were used separately or in combination (ethylene-glycol (EG), dimethylsulfoxide $\left(\mathrm{Me}_{2} \mathrm{SO}\right)$ and/or glycerol $\left.(\mathrm{G})\right)$. The respective efficiency of CPAs seems to be cell typeand/or species-dependent. The freezing protocol also strongly influenced final cell recovery. The cooling rate is one of these critical parameters: slow cooling of cells can reduce the risk of intracellular ice formation. Around the critical subzero temperature, cells are exposed to increased concentrations of solutes that may become toxic and therefore this critical temperature zone should be passed as quickly as possible. However, within the same 
temperature range, cells require a sufficient time to reduce water content in order to prevent ice formation. The combination of these two factors will determine the optimal cooling rate in different cryoprotectant agents [30]. Before transfer into LN, cell water content must be low enough to inhibit intracellular ice formation (IIF). Subsequently, the solute and /or the CPA concentration must be sufficiently high to facilitate vitrification on rapid cooling. Therefore, cells must be progressively cooled avoiding ice formation in supercooled internal solutions during transfer to LN. The importance of determining a suitable temperature at which living samples can be transferred into LN without major damages has been demonstrated in a study of cryopreservation of ragworm larvae [36].

Cell recovery from deep freezing is estimated using different tests like the Trypan blue permeation test, the MTT reduction assay, evaluation of protein content (Bradford) or DNA content (Burton test). Recovery of physiological capacities is crucial in cryopreservation processes and the use of in vitro tests allowing measurement of specific metabolic activity is of great importance in this respect. Functional tests based on metabolic activities have occasionally been applied for somatic cells. These tests involved measurement of radioactive precursor incorporation: ${ }^{3} \mathrm{H}$-leucine, ${ }^{3} \mathrm{H}$-thymidine or ${ }^{3} \mathrm{H}$-uridine to evaluate protein, DNA or RNA synthesis respectively [26, 35, 39, 40].

The present study aimed to define a protocol convenient for freezing oyster vesicular cells with high post-thaw viability levels as estimated by the MTT reduction test. Moreover, we investigated the performance of specific functional properties of these cells by in vitro measurement of glucose uptake and glycogen synthesis. 


\section{Material and methods}

\section{Animals}

Three-year-old Pacific oysters (Crassostrea gigas) were obtained from a commercial oyster farm in Saint-Vaast-la-Hougue (Normandy, France). Oysters were always used within 24 hours of reception.

\section{Preparation of vesicular cell suspensions}

Oysters (36 animals) maintained in ice during dissection were opened and thoroughly rinsed with sterile seawater. The labial palps containing vesicular cells were dissected, rinsed three times in sterile seawater and then once in Leibovitz culture medium [Leibovitz L15 (1.5\%; $\mathrm{NaCl} 340 \mathrm{mM}, \mathrm{KCl}$ 50mM, Hepes 20mM, pH 7.4, $1100 \mathrm{mOsm}$, filtered on a Millipore $0.22 \mu \mathrm{m}$ filter] supplemented with antibiotics (streptomycin $70 \mu \mathrm{M}$, penicillin $170 \mu \mathrm{M}$ ). The dissociation was performed as previously described by Berthelin et al. [3]. Briefly, tissues were minced with scissors and cells were dissociated by mechanical stirring associated with enzymatic treatment (collagenase $0.1 \% \mathrm{wt} / \mathrm{vol}$ ). Cells were then filtered through a $100 \mu \mathrm{m}$ nylon mesh and rinsed in Leibovitz medium containing antibiotics. They were then pelleted by centrifugation $\left(80 \mathrm{~g}, 30 \mathrm{~min} ., 15^{\circ} \mathrm{C}\right)$ before re-suspending in fresh culture medium at the chosen cell concentration.

\section{Freezing of cells}

Cell suspensions $\left(50 \times 10^{6}\right.$ cell $\left.\mathrm{mL}^{-1}\right)$ were pippetted into $1.8 \mathrm{ml}$ cryotubes $(0.6 \mathrm{ml}$ per tube). An equal volume of cryoprotectant solution was added at room temperature using the following stepwise additions in order to reach for each cryoprotectant agent the specific $1 \mathrm{x}$ final concentrations deteilled in Table 2 : $0.20 \mathrm{x}, 10 \mathrm{~min} ; 0.40 \mathrm{x}, 5 \mathrm{~min} ; 0.65 \mathrm{x}, 5 \mathrm{~min} ; 1 \mathrm{x}$, $10 \mathrm{~min}$. Cryoprotectant solutions were prepared by diluting CPA in modified Alsever's solution (MAS: sodium citrate $27 \mathrm{mM}$, EDTA $12 \mathrm{mM}$, sodium chloride concentration was adjusted so in order to prevent cells from being exposed to an osmolarity exceeding 2.2 Osm. $\mathrm{kg}^{-1}$ ) according to Table 2. Samples were then submitted to freezing procedures using a controlled-rate cooler (IMV-CryoBioSystem, L'Aigle, France). The freezing protocols included three phases: a stepwise first step cooling from ambient temperature to the melting temperature of each considered cryoprotectant solution, a seeding procedure, and a second stepwise cooling down to the final holding temperature before transferring into LN.

A series of controls was set up in order to measure the toxicity of each CPA and the effect of cryoprotectant treatment on frozen cell viability. Three different cooling rates were applied to the cells: $-1^{\circ} \mathrm{C} \cdot \mathrm{min}^{-1},-3^{\circ} \mathrm{C} \cdot \mathrm{min}^{-1}$ and $-5^{\circ} \mathrm{C} \cdot \mathrm{min}^{-1}$ (classically used for mollusc somatic cells $[26,40])$. Samples were transferred to liquid nitrogen at various final temperatures: $-30^{\circ} \mathrm{C},-50^{\circ} \mathrm{C}$ or $-70^{\circ} \mathrm{C}$.

\section{Thawing of cells}

After storage periods ranging from two days to seven days, samples were extracted from $\mathrm{LN}$ and thawed by immersing in a $37^{\circ} \mathrm{C}$ water bath until the last ice crystal disappeared (approximately $90 \mathrm{sec}$ ). Cryoprotectant agents were then diluted in MAS using the following stepwise decreasing concentration (initial 1x concentration for each CPA was reported in Table 2): $0.8 \mathrm{x}, 3 \mathrm{~min} ; 0.6 \mathrm{x}, 3 \mathrm{~min} ; 0.4 \mathrm{x}, 5 \mathrm{~min}, 0.1 \mathrm{x}, 10 \mathrm{~min}$ ). Cells were then 
centrifuged $\left(80 \mathrm{~g}, 30 \mathrm{~min}\right.$ at $\left.15^{\circ} \mathrm{C}\right)$, the supernatant was discarded and the pellet was resuspended in sterile Leibovitz medium containing antibiotics.

\section{MTT reduction assay}

A test based on the mitochondrial enzymatic reaction with (3-(4,5-dimethylthiazol-2yl)-2,5-diphenyltetrazolium bromide) MTT (Sigma) as a substrate and adapted to molluscan cells [32, 12] was used to evaluate cell viability. Five hundred $\mu \mathrm{l}$ of cells suspension $\left(5 \times 10^{6}\right.$ cells per ml) were incubated in a 24 well plate with 1/10 (vol:vol) MTT solution (1,2 mM in culture medium) for 24 hours at $15^{\circ} \mathrm{C}$. An equal volume of isopropanol containing $0.04 \mathrm{~N}$ $\mathrm{HCl}$ was then added to each well and after 30 min agitation, absorbance was measured at a wavelength of $570 \mathrm{~nm}$, with a reference at $630 \mathrm{~nm}$. Each value is the mean of three replicates and results were analysed using a Student's test.

\section{Glucose uptake into vesicular cells}

Five hundred $\mu \mathrm{l}$ of cell suspension were incubated in 24 well culture plates with $50 \mu \mathrm{l}$ [U- ${ }^{14} \mathrm{C}$ ]glucose $(0.5 \mu \mathrm{Ci})$ (MP-Biomedicals) and $50 \mu \mathrm{l}$ of unlabelled D-glucose $(0.5 \mathrm{mM}$ in final concentration). After three hours incubation at $15^{\circ} \mathrm{C},{ }^{14} \mathrm{C}$-glucose uptake was stopped by addition of $300 \mu \mathrm{l}$ of $20 \mathrm{mM}$ glucose. Cells were centrifuged $\left(80 \mathrm{~g}, 10 \mathrm{~min}\right.$ at $\left.15^{\circ} \mathrm{C}\right)$, rinsed three times in Leibovitz medium containing glucose $(20 \mathrm{mM})$, then dispersed in $200 \mu \mathrm{l}$ perchloric acid (15\% vol-vol in distilled water). The radioactivity was measured using a scintillation counter (Packard®) with internal quenching correction

Controls were stopped immediately after labelled glucose addition and negative controls without cells or without tracer were also performed. Each value is the mean of six replicates and results were analysed using a Student's test.

\section{$\left[\mathrm{U}-{ }^{14} \mathrm{C}\right]$ glucose incorporation into glycogen of vesicular cells}

This protocol was previously described by Berthelin et al. [3] for the same cell type. Briefly, $500 \mu \mathrm{l}$ of cell suspensions were incubated in $5 \mathrm{ml}$ sterile tubes with $50 \mu \mathrm{l}$ of [U${ }^{14}$ C]glucose $(0.5 \mu \mathrm{Ci})$ (MP-Biomedicals) and $50 \mu \mathrm{l}$ of unlabelled D-glucose (at a final concentration of $0.5 \mathrm{mM}$ ). After 20 hours incubation at $15^{\circ} \mathrm{C}$, cells were centrifuged (10000 g, $10 \mathrm{~min}) .300 \mu \mathrm{l}$ of the glycogen-containing supernatant were precipitated with ethanol (with 10mg of unlabelled glycogen as a carrier) and the glycogen was recovered by centrifugation (2500 g for $10 \mathrm{~min}$ ). After 3 washes in absolute ethanol containing D-glucose $(0.1 \mathrm{M})$, the pellet was air dried and resuspended in $500 \mu \mathrm{l}$ distilled water before counting using a scintillation counter (Packard $囚$ ).

Standards were stopped immediately after radioactive glucose addition and negative controls without cells or without tracer were also performed. Each value is the mean of six replicates and results were analysed using a Student's test.

\section{Results}

\section{Toxicity of CPA treatments}

Cell viability (MTT reduction assay) was measured in unfrozen dissociated cells previously treated with each cryoprotectant solution in order to evaluate their putative harmful effects. Results were expressed in \% viability relative to untreated cells. As shown in Figure 1, MTT values varied according to the CPA. The maximal cell loss was observed with glycerol (MTT activity decreaed by $46.9 \pm 1.6 \%$ ). The toxic effect of $\mathrm{Me}_{2} \mathrm{SO}$ (D) and ethylene glycol (E) 
treatments was less important (36.5 $\pm 0.4 \%$ and $28.8 \pm 0.5 \%$ respectively) whereas Me2SOglycerol-ethylene glycol (DGE) appeared significantly less harmful $(20.3 \pm 1.2 \%)(p<0.05)$.

\section{Thawed cell recovering}

Cell recovery after thawing was estimated by the ratio of cells surviving after freezing and thawing (MTT test) in comparison with CPA-treated cell viability before freezing. Figure 2 illustrates the respective ability of the four CPA treatments to prevent cells from cooling injury: glycerol $10 \%$ was the most efficient CPA in this respect $(91.5 \pm 5.2 \%)$ whereas the other cryoprotectant solutions were slightly less efficient (recovery rate ranging from $63.7 \pm 4.0 \%$ for DGE to $72 \pm 0.64 \%$ with $\mathrm{EG}$ )

\section{Effects of cooling rate}

Three different cooling rates, low $\left(-1^{\circ} \mathrm{C} \cdot \mathrm{min}^{-1}\right)$, intermediate $\left(-3^{\circ} \mathrm{C} \cdot \mathrm{min}^{-1}\right)$ and high $\left(-5^{\circ} \mathrm{C} \cdot \mathrm{min}^{-}\right.$ ${ }^{1}$ ) were applied during the freezing procedure using DGE (the least toxic cryoprotectant solution) and glycerol (the most efficient cryoprotectant) down to a temperature of transfer into liquid nitrogen fixed at $-50^{\circ} \mathrm{C}$. Results are presented in Figure 3 with unfrozen cells resuspended in MAS as the control. For DGE treatment, the low cooling rate $\left(-1^{\circ} \mathrm{C} . \mathrm{min}^{-1}\right)$ induced a significant improvement in cell recovery reaching $84.4 \pm 10.4 \%$. The recovery of cells subjected to the other cooling rates was significantly lower (57.6 $\pm 9.5 \%$ and $57.1 \pm 9.1 \%$ respectively for $-3^{\circ} \mathrm{C} / \mathrm{min}$ and for $-5^{\circ} \mathrm{C} / \mathrm{min}$ ). With glycerol treatment, whatever the cooling rate, the percentage of cell survival never exceeded $53 \%$.

\section{Effects of the final cooling temperature before plunging into LN}

Vesicular cells treated with DGE were cooled $\left(-3^{\circ} \mathrm{C} \cdot \mathrm{min}^{-1}\right)$ down to three distinct temperatures before transferring into LN. The effect on cell recovery of each transfer temperature is presented in Figure 4 with unfrozen cells treated with MAS as the control. The lowest transfer temperature $\left(-70^{\circ} \mathrm{C}\right)$ led to the greatest recovery $(68.5 \pm 2.2 \%)$ whereas cell viability decreased at $-50^{\circ} \mathrm{C}(51.4 \pm 2.9 \%)$ and even more so at $-30^{\circ} \mathrm{C}(34.8 \pm 6.5 \%)$.

\section{Metabolic activity of cryopreserved vesicular cells}

Glucose uptake and glucose incorporation into glycogen were compared before and after freezing of vesicular cells in the optimal conditions presented above (DGE treatment, cooling rate of $-1{ }^{\circ} \mathrm{C}$. $\mathrm{min}^{-1}$ down to $-70^{\circ} \mathrm{C}$ ). Results are expressed in percentage of metabolic activity relative to unfrozen untreated cells (Figure 5). The capacity of glucose uptake was significantly reduced after thawing (24.3 $\pm 19.7 \%$ of the initial activity for surviving cells) whereas incorporation seemed to be less affected (69.8 $\pm 29.2 \%)$. Cell viability versus the MAS control (62.1 $\pm 2.3 \%)$ confirmed the expected value.

\section{Discussion}

In order to understand the glycogen metabolism of the oyster Crassostrea gigas in relation with seasonal reproductive activity, we have developed a vesicular cell enrichment procedure based on moderate enzymatic dissociation of labial palps. Such cell suspensions have permitted in vitro measurement of ${ }^{14} \mathrm{C}$-glucose uptake (Hanquet-Dufour et al., in prep) and incorporation into glycogen [4]. Nevertheless the difficulty in undertaking studies of seasonal variations of glycogen storage and metabolism led us to envisage the banking of homogenous pools of vesicular cells in LN.

Little information is available about cryopreservation of marine invertebrate somatic cells, however it is widely accepted that the addition of cryoprotectant agents is essential to 
protect cells from freezing injury. The concentrations of CPAs required in cryopreservation procedures may cause severe toxic effects to cells. For molluscan somatic cells, different $\mathrm{CPAs}$ have been tested. Among these agents, glycerol, $\mathrm{Me}_{2} \mathrm{SO}$ and ethylene glycol were the most commonly used and the most efficient CPA concentration was close to $10 \%$ [10, 26, 34, 39, 40]. We therefore tested the ability of these CPAs to protect vesicular cells from cryoinjury. Combinations of two or more CPAs are assumed to be less toxic than a singleCPA solution because the concentration of any one component is then decreased [8]. Moreover, it is known that the toxic activity of $\mathrm{Me}_{2} \mathrm{SO}$ can be decreased by acetamide [15]. Indeed, in embryos of Crassostrea gigas, biochemical toxicity of $\mathrm{Me}_{2} \mathrm{SO}$ has been mitigated by dimethylacetamide [6]. In order to define a cryoprotectant solution as harmless as possible, a combination of three CPAs (4\% vol-vol of each in final concentration) was tested.

Since toxicity of CPAs is known to vary with cell type, a necessary preliminary step in order to define a successful cryopreservation protocol was to determine the tolerance to the selected cryoprotectant treatments. Using the metabolic MTT test to estimate cell viability, we first compared the effect of cryoprotectant agents on dissociated cells without freezing. Cell viability varied from $53 \%$ with G to $80 \%$ with DGE. Toxicity was significantly different between cryoprotectant treatments and glycerol was the most harmful, as was previously observed with Crassostrea gigas spermatozoa [23]. As expected, DGE was found to be the least toxic treatment for vesicular cells. Chao et al. [6] reported a significant reduction in toxicity to oyster embryos by the addition of glucose. Carbohydrates such as sucrose and especially trehalose have also been shown to protect cell membranes during cooling [44]. These disaccharides were successfully used for the cryopreservation of spermatozoa of the Pacific oyster $[48,1]$. However, addition of glucidic substances would interfere with glycogen metabolism and therefore this method was not used in this study.

In the second step of our study, the cryoprotective efficiency of each treatment (the ratio of survival rates after freeze-thawing and in unfrozen controls, both after CPA treatment) was compared. The results revealed that glycerol was significantly more effective than the three other treatments. However, when compared to untreated control cells, the survival rate dramatically decreased to $48.6 \pm 2.8 \%$ and was in fact lower than DGE treatment $(50.8 \pm 19.0$ $\%)$ which was significantly less toxic. The relatively low survival rates are not surprising given that cell viability was estimated with a metabolic test based on mitochondrial activity. Poncet et al. [40] observed strong variations in Haliotis tuberculata hemocyte viability according to the estimation method and showed that the survival percentages obtained with the MTT test (ranging from 30\% to 75\%) were generally lower than those obtained by protein or DNA content tests.

The optimal cooling rate should be a compromise between sufficient cell dehydration to prevent IIF and limited solute effects and $\mathrm{pH}$ variations. Optimizing cooling rate is essential in order to obtain the best cell survival. With DGE as the cryoprotectant treatment, the survival of vesicular cells is strongly influenced by the cooling rate. The slowest rate $\left(-1^{\circ} \mathrm{C} \cdot \mathrm{min}^{-1}\right)$ led to a final recovery rate reaching $84.4 \pm 10.2 \%$ compared to the unfrozen control, significantly higher than when cooled at $-3^{\circ} \mathrm{C} \cdot \mathrm{min}^{-1}$ or $-5^{\circ} \mathrm{C} \cdot \mathrm{min}^{-1}(\mathrm{p}<0.05)$. These data are in agreement with the assumption that slow cooling is required for cells having a low surface/volume ratio [13]. Such a cooling rate has also been applied to heart cells of Pecten maximus [26] and to haemocytes of Haliotis tuberculata [40].

The lower the temperature before transferring into $\mathrm{LN}$, the more dehydrated the cell should be. Therefore this parameter may greatly influence the cryopreservation success, as shown by Cheng et al. [10] on heart cells of the oyster Crassostrea virginica. In our case, the optimal temperature of transfer in liquid nitrogen was the lowest $\left(-70^{\circ} \mathrm{C}\right)$. This is in accordance with the transfer temperature used for the cryopreservation of other molluscan somatic cells, such as heart cells of Pecten maximus [26] or of Crassostrea gigas [10]. 
The optimal conditions for cryopreservation of vesicular cells were found to be: cryoprotective treatment consisting of a combination of $\mathrm{Me}_{2} \mathrm{SO}$ (4\%), glycerol (4\%) and ethyleneglycol (4\%), a cooling rate of $-1^{\circ} \mathrm{C} \cdot \mathrm{min}^{-1}$ down to $-70^{\circ} \mathrm{C}$ before transferring into $\mathrm{LN}$. In these conditions, the survival rate estimated by the MTT reduction test was about $70 \%$ (taking into account cell mortality and loss of cells during thawing and CPA-diluting procedures). However, cell viability varied slightly through the year (from 60 to 75\%) probably due to the physiological state of vesicular cells which appeared to be more sensitive when they were larger and fully loaded with glycogen reserves.

The metabolic activity of the cryopreserved vesicular cells was also investigated by measuring cellular uptake of glucose and glucose incorporation into glycogen. Glucose uptake into surviving cells was drastically affected (only $24.3 \%$ of initial activity) by the freezethawing. This loss of activity suggests that cryopreservation affected the organisation of the cell membrane and disturbed the functioning of glucose transporters just after thawing. It would be interesting to verify if this disorganisation is definitive (glucose uptake was measured over 3 hours just after thawing) or if glucose uptake could recover after a period in standard culture conditions. The addition of trehalose (which may stabilize cell membranes) to the cryoprotective solution may also be considered. The fact that glucose incorporation into glycogen (measured over a 24-hour period) of thawed cells was less affected (68\% of the initial activity) may confirm the hypothesis of temporary damage of transporters. Glycogen synthesis involves intracellular enzymes that may not be disturbed to the same extent as membrane components.

Our results confirm the possibility of successfully cryopreserving Crassostrea gigas somatic cells. However, this technique may not be suitable for investigating seasonal variations in glycogen metabolism given the reduction of glucose uptake after thawing.

\section{Acknowledgements}

The authors would like to thank I. Probert for his expert linguistic guidance. AC HanquetDufour was supported by a grant from the Conseil Régional du Calvados and SMEL (Conseil Général de la Manche). 


\section{Bibliography}

[1] S.L. Adams, J.F. Smith, R.D. Roberts, A.R. Janke, H.F. Kaspar, H.R. Tervit, P.A. Pugh, S.C. Webb, N.G. King, Cryopreservation of sperm of the Pacific oyster (Crassostrea gigas): development of the practical method for commercial spat production, Aquaculture 242 (2004) 271-282.

[2] B.L. Bayne, B. Bubel, P.A. Gabbott, D.R. Livingstone, D.M. Lowe, M.N. Moore, Glycogen utilisation and gametogenesis in Mytilus edulis (L.), Mar. Biol. Lett.3 (1982) 89-105.

[3] C. Berthelin, K. Kellner, M. Mathieu, Histological characterization and glucose incorporation into glycogen of the pacific oyster Crassostrea gigas storage cells, Mar. Biotechnol. 2 (2000a) 136-145.

[4] C. Berthelin, K. Kellner, M. Mathieu, Storage metabolism in the pacific oyster (Crassostrea gigas) in relation to summer mortalities and reproductive cycle (West Coast of France), Comp. Biochem.Physiol. 125B (2000b) 359-369.

[5] S. Bougrier, L.D. Rabenomanana, Cryopreservation of spermatozoa of the Japanese oyster, Crassostrea gigas, Aquaculture 58 (1986) 277-280.

[6] N. H. Chao, C.P. Chiang, H.W. Hsu, C.T. Tsai, T.T. Lin, Toxicity tolerance of oyster embryos to selected cryoprotectants, Aquat. Living Resour. 7 (1994) 99-104.

[7] N.H. Chao, T.T. Lin, Y.J. Chen, H.W. Hsu, I.C. Liao, Cryopreservation of late embryos and early larvae in the oyster and hard clam, Aquaculture 155 (1997) 31-44.

[8] N.H. Chao, I.C. Liao, Crypreservation of finfish and shellfish gametes and embryos, Aquaculture 197 (2001) 161-189.

[9] C.P. Chen, H.W. Hsu, S.F. Lei, C.H. Chang, Preliminary study on the cryopreservation of Pacific oyster oocytes, J. Fish. Soc. Taiwan 16 (1989) 197-201.

[10] T.C. Cheng, J.F. La Peyre, J.T. Buchanan, T.R. Tiersch, R.K. Cooper, Cryopreservation of heart cells from the eastern oyster, In vitro Cell. Dev. Biol.-Animal 37 (2001) 237-244.

[11] Y.H. Choi, Y.J. Chang, Influence of cooling rate, developmental stage, and the addition of sugar on the cryopreservation of larvae of the pearl oyster Pinctada fucata martensii, Cryobiology 45 (2003) 190-193.

[12] I. Coulon, Mise au point d'un système contrôle de culture de cœur d'huître Crassostrea gigas. Application au test de la toxicité des produits chimiques en milieu aquatique. Thèse de Doctorat, Institut National Agronomique Paris-Grignon (1993).

[13] R.S. Denniston, S. Michelet, R.A. Godke, Principles of cryopreservation. In : Tiersch, Mazix (Eds.), Cryopreservation in aquatic species. 2000, pp 59-74.

[14] Q. Dong, B. Eudeline, C. Huang, S.K. Allen, T.R. Tiersch, Commercial-scale sperm cryopreservation of diploid and tetraploid Pacific oysters, Crassostrea gigas, Cryobiology 50 (2005) 1-16. 
[15] G.M. Fahy, The relevance of cryoprotectant "toxicity" to cryobiology. Cryobiology 23 (1986) 1-13.

[16] P.A. Gabbott, M.A. Whittle, Glycogen synthetase in the sea mussel Mytilus edulis L.-II. Seasonal changes in glycogen content and glycogen synthetase activity in the mantle tissue, Comp. Biochem. Physiol., 83B (1985) 197-207.

[17] J.C. Gwo, C.Y. Wu, W.S. Chang, H.Y. Cheng, Evaluation of damage in Pacific oyster (Crassostrea gigas) spermatozoa before and after cryopreservation using comet assay, Cryo letters 24 (2003) 171-180.

[18] J.C. Gwo, C.W. Chen, H.Y. Cheng, Semen cryopreservation of small abalone (Haliotis diversicolor supertaxa), Theriogenology 58 (2002) 1563-1578.

[19] J.-C. Gwo, Crypreservation of oyster (Crassostrea gigas) embryos, Theriogenology 43 (1995) 1163-1174.

[20] C. Heude-Berthelin, J. Laisney, J. Espinosa, O. Martin, G. Hernandez, M. Mathieu, K. Kellner, Storage and reproductive strategy in Crassostrea gigas from two different growing areas (Normandy and the Atlantic coast, France), Invertebrate Reproduction and development, 40 (2001) 79-86.

[21] C. Heude-Berthelin, B. Fievet, G. Leclerc, P. Germain, K. Kellner, M. Mathieu, In vivo and in vitro approaches to the analysis of glycogen metabolism in the pacific oyster, Crassostrea gigas, J. Shellfish Research 22 (2003) 715-721.

[22] J.B. Hughes, An examination of eggs challenged with cryopreserved spermatozoa of the American oyster, Crassostrea virginica, Cryobiology 10 (1973) 342-344.

[23] S. Ieropoli, P. Masullo, M. Do Espirito Santo, G. Sansone, Effects of extender composition, cooling rate and freezing on the fertilisation viability of spermatozoa of the Pacific oyster (Crassostrea gigas), Cryobiology 49 (2004) 250-257.

[24] H. Kurokura, K. Namba, T. Ishikawa, Lesions of spermatozoa by cryopreservation in oyster Crassostrea gigas, Nippon Suisan Gakkaishi 56 (1990) 1803-1806.

[25] J.E. Lennan, Experimental self-fertilization of the Pacific oyster Crassostrea gigas, utilizing cryopreserved sperm, Genetics 68 (1971) 599-601.

[26] F. Le Marrec-Croq, K. Fristayre, C. Chesne, A. Guillozou, G. Dorange, Cryopreservation of Pecten maximus heart cells, Cryobiology 37 (1998) 200-206.

[27] T.T. Lin, N.H. Chao, H.T Tung, Factors affecting survival of cryopreserved oyster (Crassostrea gigas) embryos, Cryobiology 39 (1999) 192-196.

[28] T.T. Lin, H.T. Tung, N.H. Chao, Cryopreservation of oyster embryos with conventional freezing procedure and vitrification. Cryobiology 30 (1993) 614-615. 
[29] M. Mathieu, P. Lubet, Storage tissue metabolism and reproduction in marine bivalves- a brief review, I R D 23 (2-3) (1993), 123-129.

[30] P. Mazur, Freezing of living cells: mechanisms and implications, Am. J. Physiol. 247C (1984) 125-142.

[31] I.R.B. McFadzen, Cryopreservation of the sperm of the Pacific oyster Crassostrea gigas, Meth. Mol. Biol. 38 (1995) 145-149.

[32] T. Mosmann, Rapid colorimetric assay for cellular growth and survival : Application to proliferation and cytotoxicity assays, Journal of Immunological Methods, 65 (1983) 55-63.

[33] T. Naidenko, Cryopeservation of Crassostrea gigas oocytes, embryos and larvae using antioxydant echinochrome A and antifreeze protein AFP1, Cryo-Letters 18 (1997) 375-382.

[34] N.A. Odintsova, L. Tsal, Cryopreservation of primary cell cultures of Bivalvia, CryoLetters 16 (1995) 13-20.

[35] N.A. Odintsova, K. Kiselev, N. Sanina, E. Kostetsky, Cryopreservation of primary cell cultures of marine invertebrates, Cryo-letters 22 (2001) 299-310.

[36] P.J.W. Olive, W.B. Wang, Cryopreservation of Nereis virens (Polychaeta, Annelida) larvae: the mechanism of cryopreservation of differenciated metazoan. Cryobiology 34 (1997) 284-294.

[37] C.G. Paniagua-Chavez, J.T. Buchanan, T.R. Tiersch, Effect of extender solutions and dilution on motility and fertilizing ability of eastern oyster sperm, J. Shellfish Res. 17 (1998) 231-237.

[38] C.G. Paniagua-Chavez, T.R. Tiersch, Laboratory studies of cryopreservation of sperm and trocophore larvae of the Eastern oyster, Cryobiology 43 (2001) 211-223.

[39] J.M. Poncet, A. Serpentini, E. Boucaud-Camou, J.M. Lebel, Cryopreservation of mantle dissiciated cells from Haliotis tuberculata (Gasteropoda) and postthaw primary cell cultures, Cryobiology 44 (2002) 38-45.

[40] J.M. Poncet, J.M. Lebel, Influence of cryoprotectant agent and cooling rate on frozen and thawed hemocytes from the Mollusk Haliotis tuberculata, Cryobiology 47 (2003) 184189.

[41] P. Renard, Cooling and freezing tolerences in embryos of the pacific oyster, Crassostrea gigas : methanol and sucrose effets, Aquaculture, 92 (1991) 43-57.

[42] P. Renard, J.C. Cochard, Effect of various cryoprotectants on Pacific oyster Crassostrea gigas Thunberg, Manila clam Ruditapes philippinarum Reeve and King scallop Pecten maximus (L) embryos: influence of the biochemical and osmotic effects, Cryo-Letters 10 (1989) 169-180. 
[43] C. Ruiz, D. Martinez, G. Mosquera, M. Abad, J.L. Sanchez, Seasonal variations in condition, reproductive activity and biochemical composition of the flat oyster, Ostrea edulis, from San Cibran (Galicia, Spain), Mar. Biol., 112 (1992) 67-74.

[44] A.S. Rudolph, J.H. Crowe, Membrane stabilization during freezing: the role of two natural cryoprotectants, trehalose and praline, Cryobiology 22 (1985) 367-377.

[45] J.D. Toledo, H. Kurokura, S. Kasahara, Preliminary studies on the cryopreservation of Blue mussel embryos, Nippon Suisan Gakkaishi 65 (1989) 1661.

[46] H.P. Tsai, N.H. Chao, Cryopreservation of small abalone (Haliotis diversicolor) sperm Technique and its significance, J. Fish. Soc. Taiwan 21 (1994) 347-360.

[47] H. Usuki, M. Hamaguchi, H. Ishioka, Effects of developmental stage, seawater concentration and rearing temperature on cryopreservation of Pacific oyster Crassostrea gigas larvae, Fish. Sci. 68 (2002) 757-762.

[48] H. Usuki, M. Hamaguchi, H. Ishioka, Cryopreservation of Pacific oyster sperm and larvae, Bull. Natl. Res. Inst. Aquacult. S1 (1999) 3-6.

[49] G. Van der Horst, H.M. Dott, J.S. Samuels, A. Genade, Short- and long-term storage of viable oyster sperm, S. Afr. J. Sci. 81 (1985) 404-405

[50] K. Yankson, J. Moyse, Cryopreservation of the spermatozoa of Crassostrea tulipa and tree other oysters. Aquaculture, 97 (1991) 259-267.

[51] S.R. Zell, M.H. Bamford, H. Hidu, Cryopreservation of spermatozoa of american oyster, Crassostrea virginica Gmelin, Cryobiology, 16 (1979) 448-460. 
Table 2: Composition of the different cryoprotectant solutions

\begin{tabular}{|c|c|c|}
\hline Designation & Cryoprotectant agent & Dilution in MAS \\
\hline D & Me ${ }_{2} \mathrm{SO}$ & $10 \%$ \\
G & Glycerol & $10 \%$ \\
E & Ethylene glycol & $10 \%$ \\
DGE & Me 2 SO & $4 \%$ \\
& Glycerol & $4 \%$ \\
& Ethylene glycol & \\
\hline
\end{tabular}




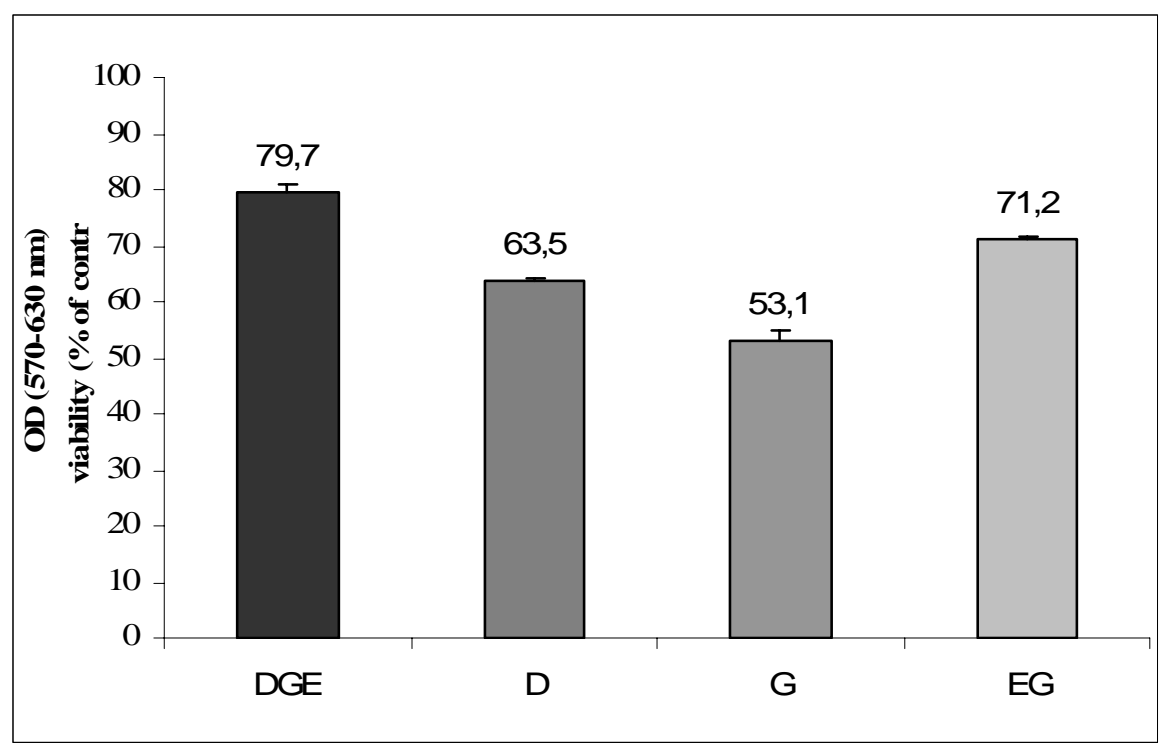

Figure 1: Toxicity of CPA treatments (cooling at the temperature rate of $3^{\circ} \mathrm{C} /$ min until $-50^{\circ} \mathrm{C}$ before transfer into LN) estimated by MTT reduction assay in treated unfrozen cells visa untreated control (expressed in percentage of control). Each data point represents the means +/- SD of 3 replicates.

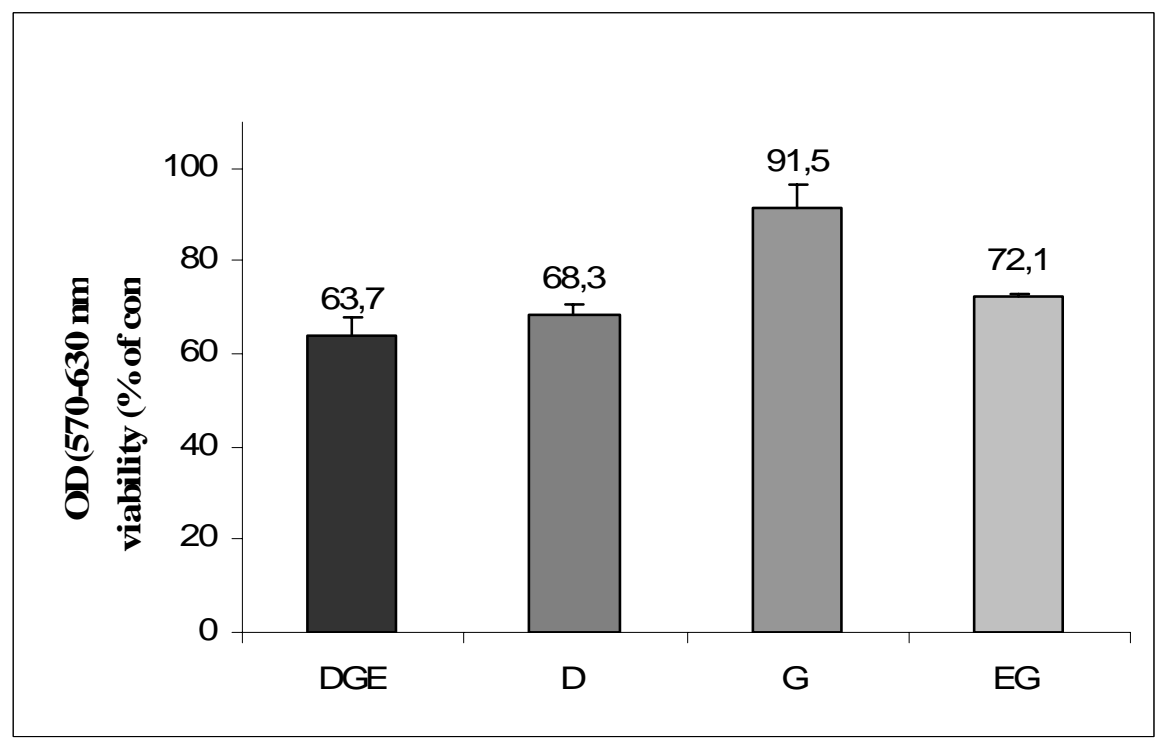

Figure 2: Cell recovery after thawing.For each CPA treatment, cells were cooled at $3^{\circ} \mathrm{C} / \mathrm{min}$ until $-50^{\circ} \mathrm{C}$ before transfer into LN. The efficiency was estimated by MTT reduction assay after freezing and thawing (expressed in percentage of CPA treated unfrozen cells). Each data point represents the means +/- SD of 3 replicates. 

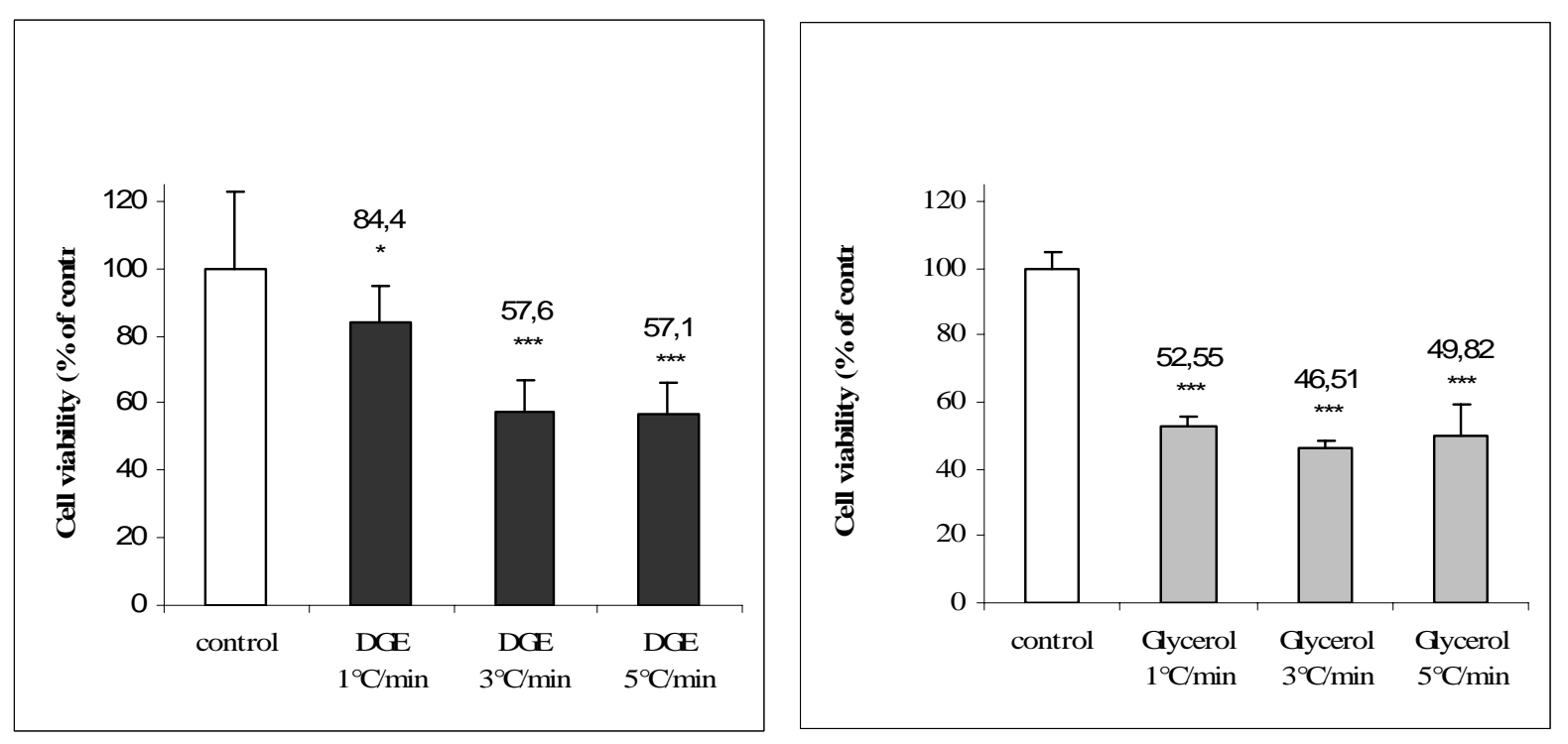

Figure 3: Effect of the cooling rate $\left(-1 ;-3 ;-5^{\circ} \mathrm{C} / \mathrm{min}\right)$ using (a) DGE or (b) Glycerol as CPA . Cell viability was estimated with the MTT reduction assay and expressed as \% of unfrozen MAS treated cells. Samples were cooled down to $-50^{\circ} \mathrm{C}$ before transfer into LN.Each data point represents the means $+/$ - SD of 5 replicates. Significant differences from control cell were indicated: * $\mathrm{P}<0.05$; $* * \mathrm{P}<0.01 ; * * * \mathrm{P}<0.001$ (student test). 


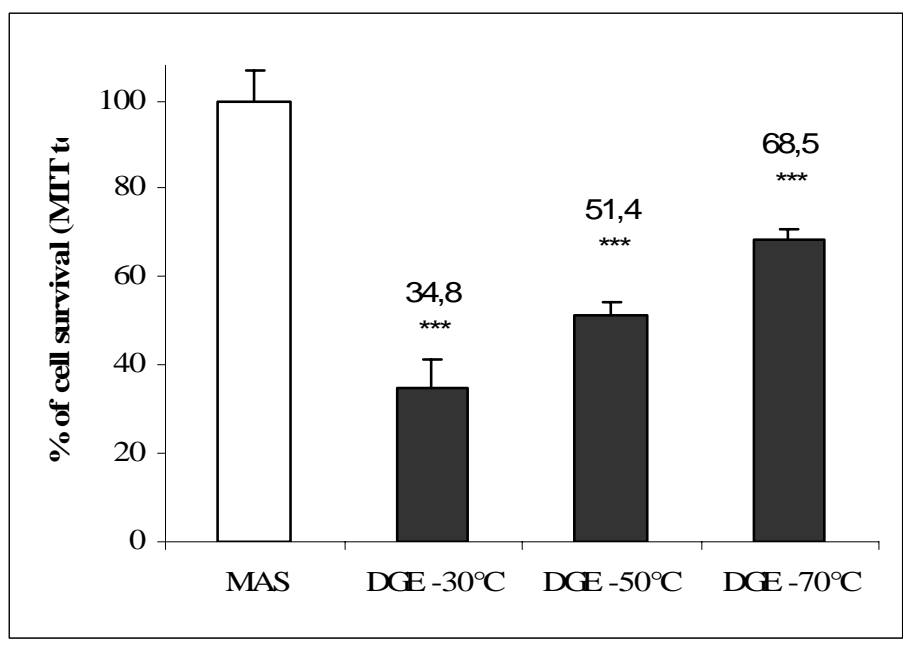

Figure 4: Effect of final cooling temperature before transfer into LN with DGE as CPA. Three temperatures were compared $\left(-30^{\circ} \mathrm{C},-50^{\circ} \mathrm{C}\right.$ and $70^{\circ} \mathrm{C}$ ) at the intermediate cooling rate $-3^{\circ} \mathrm{C} / \mathrm{min}$ and survival was estimated according to the MTT reduction assay. Each data point represents the means $+/-$ SD of 5 replicates. Significant differences visa MAS treated cells were indicated: * $\mathrm{P}<0.05$; ** $\mathrm{P}<0.01$; *** $\mathrm{P}<0.001$ (Student test). 


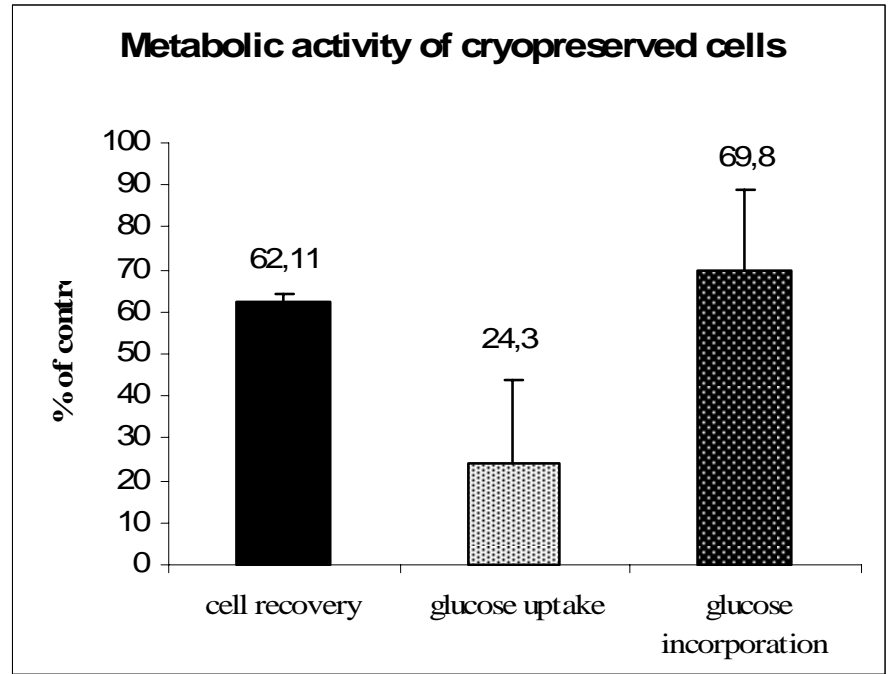

Figure 5: Metabolic activity of thawed cells $\left(-1^{\circ} \mathrm{C} / \mathrm{min}\right.$, DGE treatment, transfer into $\mathrm{LN}$ at $-70^{\circ} \mathrm{C}$ ) estimated by glucose uptake into vesicular cells and glucose incorporation into glycogen. Results were expressed in $\%$ of untreated cells activity. Each data point represents the means +/SD of 5 replicates 


\begin{tabular}{|c|c|c|c|c|}
\hline Species & cell type & CPA & $\begin{array}{l}\text { test of viability or } \\
\text { cell activity }\end{array}$ & Reference \\
\hline Crassostrea tulipa & spermatozoa & $\mathrm{Me}_{2} \mathrm{SO}$ & fertility & [50] \\
\hline Crassostrea virginica & $\begin{array}{l}\text { larvae } \\
\text { spermatozoa } \\
\text { heart cells }\end{array}$ & $\begin{array}{l}\text { Propylene glycol } \\
\text { Propylene glycol } \\
\mathrm{Me}_{2} \mathrm{SO} \\
\mathrm{Me}_{2} \mathrm{SO}, \text { Glycerol, } \\
\text { Propylene glycol }\end{array}$ & $\begin{array}{l}\text { survival, growth } \\
\text { fertility } \\
\text { MTT }\end{array}$ & $\begin{array}{l}{[37]} \\
{[38,51,22]} \\
{[10]}\end{array}$ \\
\hline Crassostrea gigas & $\begin{array}{l}\text { spermatozoa } \\
\text { spermatozoa 2n } \\
\text { oocytes } \\
\text { embryos } \\
\text { larvae }\end{array}$ & $\begin{array}{l}\mathrm{Me}_{2} \mathrm{SO} \\
\mathrm{Me}_{2} \mathrm{SO} \text {, Trehalose } \\
\text { Ethylene glycol } \\
\text { Propylene glycol } \\
\text { Glycerol } \\
\mathrm{Me}_{2} \mathrm{SO} \\
\mathrm{Me}_{2} \mathrm{SO} \\
\mathrm{Glycerol} \\
\mathrm{Propylene} \mathrm{glycol,}_{\text {Glycerol }} \\
\text { Ethylene glycol, Me} 2 \mathrm{SO} \\
\mathrm{Me}_{2} \mathrm{SO} \text {, Ethylene glycol } \\
\mathrm{Me}_{2} \mathrm{SO} \\
\text { Propanediol, Methanol } \\
\text { Sucrose } \\
\text { Me} 2 \mathrm{SO}\end{array}$ & $\begin{array}{l}\text { fertility } \\
\text { eosine-nigrosine } \\
\text { fertility } \\
\text { comet assay } \\
\text { fertility } \\
\text { fertility } \\
\text { viability } \\
\text { embryonic development } \\
\text { development } \\
\text { viability }\end{array}$ & $\begin{array}{l}{[23,48,49]} \\
{[24]} \\
{[1,31]} \\
{[25]} \\
{[5]} \\
{[17]} \\
{[14]} \\
{[9]} \\
{[33]} \\
{[19]} \\
{[6]} \\
{[28]} \\
{[7]} \\
{[42]} \\
{[33,41]} \\
{[33]} \\
{[48]}\end{array}$ \\
\hline Pinctada fucata & larvae & $\mathrm{Me}_{2} \mathrm{SO}$ & viability & [11] \\
\hline Pecten maximus & $\begin{array}{l}\text { heart cells } \\
\text { embryos }\end{array}$ & $\begin{array}{l}\mathrm{Me}_{2} \mathrm{SO} \\
\\
\text { Ethylene glycol } \\
\text { Propanediol, Methanol } \\
\mathrm{Me}_{2} \mathrm{SO}, \text { Glycerol, } \\
\text { sucrose }\end{array}$ & $\begin{array}{l}\text { Trypan blue, Bradford } \\
{\left[{ }^{3} \mathrm{H}\right] \text { thymidine }} \\
\text { incorporation } \\
{\left[{ }^{14} \mathrm{C}\right] \text { leucine incorporation }} \\
\text { viability }\end{array}$ & $\begin{array}{l}{[26]} \\
{[42]}\end{array}$ \\
\hline Ruditapes philippinarum & embryos & $\begin{array}{l}\text { Ethylene glycol } \\
\text { Propanediol, Methanol } \\
\mathrm{Me}_{2} \mathrm{SO} \text {, Glycerol, } \\
\text { Sucrose }\end{array}$ & viability & [42] \\
\hline $\begin{array}{l}\text { Mizuchopecten } \\
\text { yessoensis }\end{array}$ & $\begin{array}{l}\text { primary culture } \\
\text { embryo cells } \\
\text { digestive gland cells }\end{array}$ & $\begin{array}{l}\mathrm{Me}_{2} \mathrm{SO} \text {, Glycerol, } \\
\text { Trehalose }\end{array}$ & $\begin{array}{l}\text { Trypan blue } \\
{\left[{ }^{3} \mathrm{H}\right] \text {-uridine incorporation }}\end{array}$ & $\begin{array}{l}{[34]} \\
{[35]}\end{array}$ \\
\hline Mytilus trossulus & primary culture & $\mathrm{Me}_{2} \mathrm{SO}$ & {$\left[{ }^{3} \mathrm{H}\right]$-uridine incorporation } & [34] \\
\hline
\end{tabular}




\begin{tabular}{|l|l|l|l|l|} 
& $\begin{array}{l}\text { mantle, gills, } \\
\text { muscles }\end{array}$ & & & {$[35]$} \\
\hline Mytilus edulis & embryos & $\mathrm{Me}_{2} \mathrm{SO}$ & viability & {$[45]$} \\
\hline Meretrix lusoria & embryos & $\mathrm{Me}_{2} \mathrm{SO}$ & development & {$[7]$} \\
\hline Haliotis tuberculata & $\begin{array}{l}\text { mantle cells } \\
\text { hemocytes }\end{array}$ & $\begin{array}{l}\mathrm{Me} 2 \mathrm{SO}, \text { Glycerol } \\
\text { Ethylene glycol }\end{array}$ & $\begin{array}{l}\text { MTT, Bradford, Burton test, } \\
\text { alkalin phosphatase activity } \\
{\left[{ }^{3} \mathrm{H}\right] \text {-Leucine incorporation }}\end{array}$ & $\begin{array}{l}{[39]} \\
{[40]}\end{array}$ \\
\hline Haliotis diversicolor & spermatozoa & $\begin{array}{l}\mathrm{Me} 2 \mathrm{SO}, \text { Glucose } \\
\mathrm{Me}_{2} \mathrm{SO}\end{array}$ & fertility & $\begin{array}{l}{[46]} \\
{[18]}\end{array}$
\end{tabular}

Table 1: Cryopreservation and molluscan species: cell type, nature of cryoprotectant agent (CPA) and test of viability or cell activity. 